\title{
2,2'-Dihydroxychalcone, a glutathione transferase inhibitor, sensitises human colon adenocarcinoma cells to chlorambucil and melphalan, but not to actinomycin D
}

\author{
KENNETH GOH ${ }^{1}$, YUFAN CHEN ${ }^{1}$, LIN ZHENG ${ }^{1}$, LAICHUN ONG ${ }^{1}$, YI JIN ${ }^{1}$, PIERCE CHOW ${ }^{2}$ and KAI ZHANG $^{1}$ \\ ${ }^{1}$ Department of Experimental Surgery, Singapore General Hospital; ${ }^{2}$ Department of General Surgery, \\ Singapore General Hospital and Duke-NUS Graduate Medical School, Singapore 169608
}

Received February 1,2008; Accepted April 7, 2008

\begin{abstract}
Dihydroxychalcone (2,2'DHC) is a potent inhibitor of glutathione S-transferases (GSTs). Pre-treatment of human colon cancer cells by a non-toxic concentration of this GST inhibitor significantly sensitised cancer cells to chlorambucil and melphalan, which are substrates of glutathione (GSH) conjugation. However, sensitisation to actinomycin D, which has not been shown to be detoxified by GSH-related mechanisms, was not observed. These results further confirm the contribution of GSH-related mechanisms to drug resistance by increased detoxification of drugs. 2,2'DHC inhibited GST activity and the transport of GSH conjugates by cancer cells. Its combined effects on GST and glutathione conjugate export (GS-X) pump may provide more potent sensitisation of cancer cells to chemotherapeutic drugs.
\end{abstract}

\section{Introduction}

Chemotherapy has been widely used as a strategy for the treatment of a variety of malignancies, including colon cancers (1-3). However, its clinical effectiveness is significantly affected by cellular drug resistance. Various biochemical and molecular mechanisms of cellular resistance to these chemotherapeutic agents have been proposed (4). Glutathione (GSH), GSH-related enzymes and glutathione conjugate export (GS-X) pump have been shown to participate in the detoxification of many anticancer drugs, including melphalan and chlorambucil (5-7). Previous studies have indicated that plant polyphenols sensitise human tumour cells to chlorambucil by inhibiting GST activity (8), glutathione reductase (GSH-RD) (9) and the transport of GSH conjugates $(8,10)$. Increased expression of glutathione S-transferase (GST) (11) and GS-X pump (12) was

Correspondence to: Dr Kai Zhang, Department of Experimental Surgery, BLK 9, Level 3, Singapore General Hospital, Outram Road, Singapore 169608

E-mail: zhang.kai@sgh.com.sg

Key words: 2,2'-dihydroxychalcone, chlorambucil, melphalan, actinomycin D, glutathione S-transferase, glutathione conjugate export pump, human colon adenocarcinoma cells also observed in melphalan-resistant tumour cells. Moreover, the inhibition of GST by ethacrynic acid (13-15) and the depletion of GSH by buthionine sulphoximine (16) potentiated melphalan cytotoxicity in tumour cells. These studies suggest that GSH, GSH-related enzymes and GS-X pump contribute to cell resistance to anticancer drugs such as melphalan and chlorambucil, both of which are substrates of the detoxification system. However, none of these GSH-related factors act independently; their modulation alone may be insufficient for the sensitisation of drug-resistant cells.

Studies of sensitivity to chemotherapeutic drugs that cannot be detoxified by GSH-related mechanisms may provide information useful for understanding other possible mechanisms of drug detoxification inhibition. Currently, this knowledge is quite limited. Actinomycin D, as a non-covalent DNA-binding drug inhibiting DNA-directed RNA and DNA synthesis, is used clinically to treat Wilm's and Ewing's tumours and soft tissue sarcomas $(17,18)$. This anticancer drug is not metabolised in animals (19), and no report has shown its detoxification by GSH-related mechanisms $(20,21)$. In our previous study, the activity of GSH-related factors was found to be correlated to the sensitivity of human cancer cells to chlorambucil and adriamycin (22), but not to actinomycin D (23). This suggests that GSH-related mechanisms contribute to drug resistance by means of increased drug detoxification. In the present study, we further examined the effect of 2,2'dihydroxychalcone (2,2'DHC), a modulator of GSH-related mechanisms, on the sensitivity of human colon cancer cells to chlorambucil and melphalan, which are substrates of GSHrelated mechanisms, and to actinomycin $\mathrm{D}$, which has not been shown to be detoxified by the system. The aim of this comparative study was to provide additional valuable information on the subject.

\section{Materials and methods}

Chemicals. Melphalan, chlorambucil, actinomycin D, GSH, 1-chloro-2,4-dinitrobenzene (CDNB) and 3-[4,5-dimethylthiazol-2yl]-2,5-diphenyltetrazolium bromide (MTT) were purchased from Sigma Chemical Co. (St. Louis, MO, USA). Tissue culture flasks and multi-well plates were from Nunclon (Resklide, Denmark). RPMI-1640 medium, MEM medium and foetal calf serum (FCS) were Gibco products from Life 
Technologies (Grand Island, NY, USA). Other chemicals of analytical grade were from the usual commercial suppliers.

Culture of human tumour cells. Human tumour cell line 220.1 (colon adenocarcinoma) was obtained from the Institute of Molecular and Cellular Biology, National University of Singapore. The cells were grown in RPMI-1640 medium containing $1 \mathrm{mM}$ sodium pyruvate, $1 \mathrm{mM}$ non-essential amino acid and $10 \%$ FCS. Cells were maintained in a humidified atmosphere of air/ $\mathrm{CO}_{2}(19 / 1)$ and were subcultured every 2-3 days.

Assay of cytotoxicity. Cells $\left(\sim 1 \times 10^{4}\right)$ were seeded in each well of 96-well tissue culture plates and incubated in a $\mathrm{CO}_{2}$ incubator for $24 \mathrm{~h}$. The cells were pre-treated with $10 \mu \mathrm{M}$ 2,2'DHC for $1 \mathrm{~h}$. Stock solutions of chlorambucil, melphalan and actinomycin D were freshly prepared in absolute ethanol, and aliquots of the stock solutions were added to the wells of the plates at the desired concentrations. After $24 \mathrm{~h}$ incubation with chlorambucil, melphalan and actinomycin $\mathrm{D}$, the number of surviving cells in the plate wells was determined by MTT assay as previously reported (24). To each well, $25 \mu 1$ of the $5 \mathrm{mg} / \mathrm{ml}$ MTT stock solution was added; after $2 \mathrm{~h}$ incubation at $37^{\circ} \mathrm{C}, 100 \mu \mathrm{l}$ of the extraction buffer $(20 \% \mathrm{SDS} w / \mathrm{v}$ in $50 \% \mathrm{~N}, \mathrm{~N}$-dimethyl formamide $\mathrm{v} / \mathrm{v}, 2.5 \%$ of $80 \%$ acetic acid and $2.5 \% 1 \mathrm{~N} \mathrm{HCl}, \mathrm{pH} 4.7$ ) was added. After incubation overnight at $37^{\circ} \mathrm{C}$, optical densities at a wavelength of $570 \mathrm{~nm}$ were measured using a microplate reader (Dynatech Laboratories). Cell survival for each dose of chlorambucil, melphalan and actinomycin D was calculated as the ratio of absorbance in the wells containing the drug-treated cells to that of the control wells. $\mathrm{IC}_{50}$ values were calculated from dose-dependent curves in the linear range.

Assay of GST activities. Cells $\left(\sim 1 \times 10^{7}\right)$ were harvested by trypsinisation. Cell homogenates prepared by a polytron homogeniser were then centrifuged at $105,000 \mathrm{x} g$ for $45 \mathrm{~min}$ at $4^{\circ} \mathrm{C}$. The GST activities of the cytosol preparations (the supernatant) of the human tumour cells were measured according to the method of Habig et al (25). The reaction mixture contained $125 \mathrm{mM}$ potassium phosphate buffer, $\mathrm{pH} 6.5,1 \mathrm{mM}$ GSH and $1 \mathrm{mM}$ CDNB. The reaction was activated by the addition of GST to the cytosol preparations of human tumour cells. The rate of formation of GSH and CDNB conjugate was determined spectrophotometrically by monitoring absorbance at $340 \mathrm{~nm}$. GST activities were expressed as nmol of dinitrophenyl-S-glutathione (DNP-SG) formed $/ \mathrm{min} / \mathrm{mg}$ of protein at $37^{\circ} \mathrm{C}$, taking the extinction coefficient as $9.6 \mathrm{mM}^{-1} \mathrm{~cm}^{-1}(25)$. For the inhibition study, inhibitor was added to the reaction mixture at the final concentrations shown in Table $\mathrm{I}_{\text {. }} \mathrm{IC}_{50}$ values were calculated by linear regression from the doseresponse curves.

Measurement of GS-X pump activities of human tumour cells. Cells were cultured on a 6 -well plate at a density of $1.0 \times 10^{6}$ cells/well/2 $\mathrm{ml}$ in a $\mathrm{CO}_{2}$ incubator for $24 \mathrm{~h}$. They were then incubated with $1 \mathrm{mM} \mathrm{CDNB}$ at $10^{\circ} \mathrm{C}$ for $45 \mathrm{~min}$ for DNP-SG loading. The formation of DNP-SG inside human tumour cells was described in our previous study (10). Cells in the wells were washed three times with $1 \mathrm{ml} \mathrm{Hank's} \mathrm{Balanced} \mathrm{Salt}$ Solution (HBSS), then incubated in $\mathrm{HBSS}$ at $37^{\circ} \mathrm{C}$ for up to
Table I. Inhibition of glutathione S-transferase activity in human colon adenocarcinoma cells by 2,2'-dihydroxychalcone ${ }^{\mathrm{a}}$.

\begin{tabular}{lc}
$\begin{array}{l}\text { Concentration of } \\
2,2^{\prime} \mathrm{DHC}(\mu \mathrm{M})\end{array}$ & $\begin{array}{c}\text { GST activity } \\
\mathrm{nmol} / \mathrm{min} / \mathrm{mg} \text { protein }(\% \text { inhibition })\end{array}$ \\
\hline 0 (control) & $82.0 \pm 1.5(0.0)$ \\
10 & $71.1 \pm 1.4(13.3)$ \\
20 & $58.8 \pm 1.4(28.3)$ \\
40 & $22.2 \pm 0.5(72.9)$ \\
80 & $17.9 \pm 0.3(78.1)$ \\
160 & $6.2 \pm 0.0(92.4)$ \\
\hline
\end{tabular}

${ }^{\mathrm{a}}$ Glutathione S-transferase (GST) was extracted from the cells, then it activity was determined spectrophotometrically using CDNB as an electrophilic substrate. Values are the means \pm SD of at least three independent experiments.

60 min. The DNP-SG content exported to the extracellular HBSS by the cells was quantified by the HPLC-UV method as described previously (10). Extracellular HBSS (0.5 ml) was passed through a $0.45-\mu \mathrm{m}$ filter, then $100 \mu 1$ of the filtrate was injected for HPLC-UV analysis using an HP 1100 liquid chromatographic system and a variable wavelength detector set at $340 \mathrm{~nm}$. The column $(100 \times 4.6 \mathrm{~mm})$ was packed with $\mathrm{C}_{18}$ Hypersil ODS, and elution was carried out with a gradient of $40-90 \%$ (v/v) methanol in $0.01 \mathrm{M}$ sodium phosphate, $\mathrm{pH}$ 6.0, for $6 \mathrm{~min}$. The flow rate was $1 \mathrm{ml} / \mathrm{min}$. The peak representing DNP-SG at the retention time of $2.1 \mathrm{~min}$ was quantified by comparison with DNP-SG standards formed from 1-40 nmol $\mathrm{CDNB} / \mathrm{ml}$ in the presence of excess GSH and rat liver GSTs purified by S-hexylglutathione affinity chromatography (26). GS-X pump activity shown as the rate of DNP-SG efflux from the human tumour cells was calculated and expressed as $\mathrm{nmol} / 10^{6}$ cells $/ \mathrm{h}$ at $37^{\circ} \mathrm{C}$.

Protein determination. The protein contents of the cytosol preparations were measured by the method of Bradford et al (27) using Bio-Rad reagent with bovine serum albumin (BSA) as a standard.

Statistical analysis. The differences between cells treated with drugs only and cells treated with both drugs and the sensitiser were statistically analysed using the Student's t-test. p-values were obtained using Microsoft Excel (Redmond, WA, USA). A p-value $<0.05$ was considered statistically significant.

\section{Results}

2,2'-Dihydroxychalcone sensitises human colon tumour cells to melphalan and chlorambucil, but not to actinomycin D. Dose-dependent cytotoxicity of chlorambucil and melphalan was observed in the human colon adenocarcinoma cells. As shown in Figs. 1 and 2, pre-treatment of the cells with $10 \mu \mathrm{M}$ 2,2'DHC significantly sensitised them to chlorambucil and melphalan. When the cells were treated with $40 \mu \mathrm{M}$ melphalan, the toxicity of the drug was potentiated by $50 \%$. Upon 


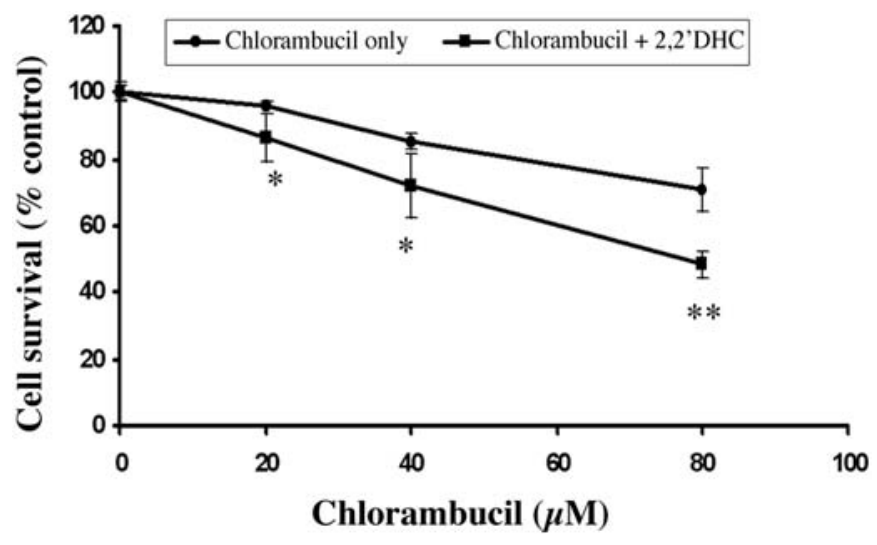

Figure 1. Sensitisation of human colon adenocarcinoma cells by 2,2 -dihydroxychalcone $(2,2$ 'DHC) to chlorambucil. Cells were pre-incubated with 2,2 'DHC for $1 \mathrm{~h}$ then incubated with chlorambucil for $24 \mathrm{~h}$. Cell survival was determined by MTT assay and expressed as a percentage of the control cells. ${ }^{*}$ Compared with chlorambucil only, $\mathrm{p}<0.05 ;{ }^{* *}$ compared with chlorambucil only, $\mathrm{p}<0.01$.

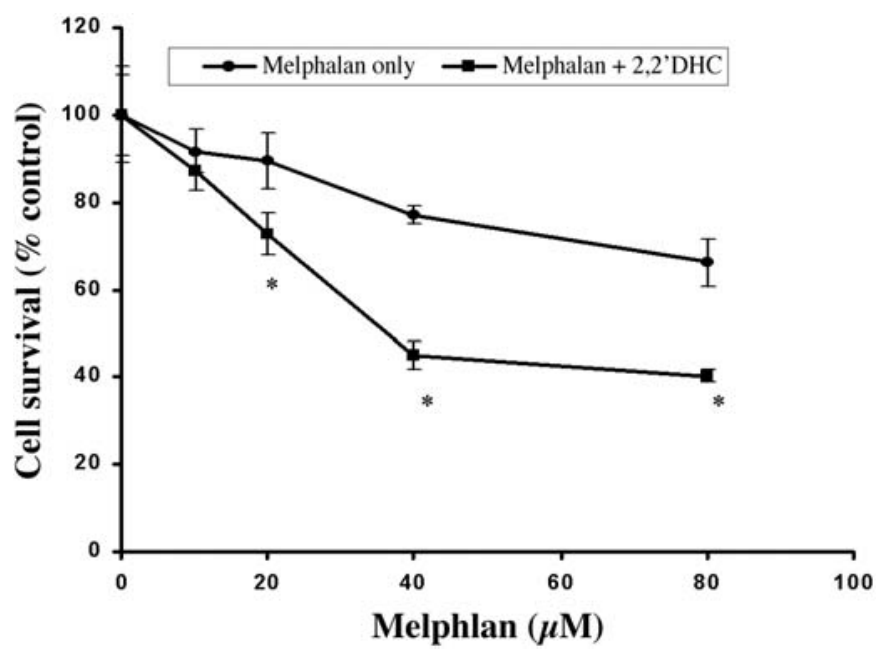

Figure 2. Sensitisation of human colon adenocarcinoma cells by 2,2'-dihydroxychalcone $\left(2,2^{\prime} \mathrm{DHC}\right)$ to melphalan. Cells were pre-incubated with $2,2^{\prime} \mathrm{DHC}$ for $1 \mathrm{~h}$ then incubated with melphalan for $24 \mathrm{~h}$. Cell survival was determined by MTT assay and expressed as a percentage of the control cells. ${ }^{*}$ Compared with melphalan only, $\mathrm{p}<0.01$.

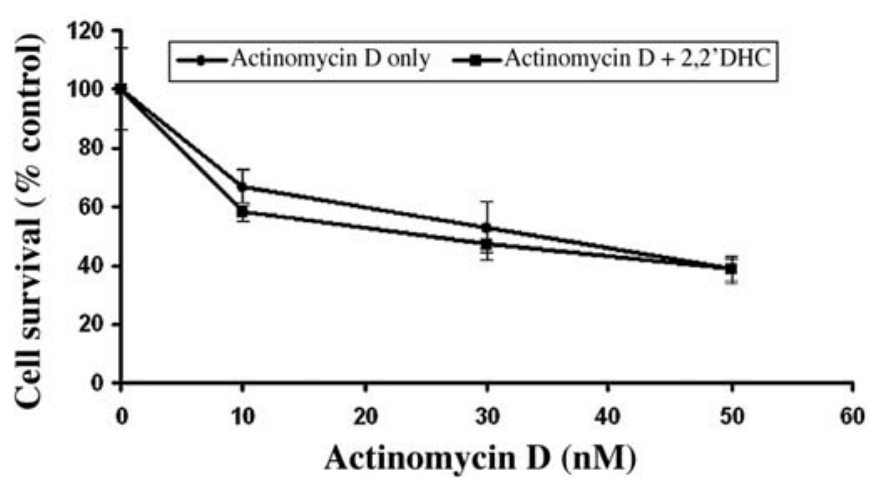

Figure 3. Sensitisation of human colon adenocarcinoma cells by 2,2'-dihydroxylchalcone $\left(2,2^{\prime} \mathrm{DHC}\right)$ to actinomycin D. Cells were pre-incubated with $2,2^{\prime} \mathrm{DHC}$ for $1 \mathrm{~h}$ then incubated with actinomycin D for $24 \mathrm{~h}$. Cell survival was determined by MTT assay and expressed as a percentage of the control cells.
Table II. Inhibition of glutathione conjugate export pump activity in human colon adenocarcinoma cells by 2,2 '-dihydroxychalcone ${ }^{\mathrm{a}}$.

\begin{tabular}{lc}
\hline $\begin{array}{l}\text { Concentration of } \\
2,2 \mathrm{DHC}(\mu \mathrm{M})\end{array}$ & $\begin{array}{c}\text { GS-X pump activity } \\
\mathrm{nmol} / 10^{6} \text { cells/h }(\% \text { inhibition })\end{array}$ \\
\hline 0 (control) & $1.36 \pm 0.054 \quad(0)$ \\
20 & $1.10 \pm 0.034(19)$ \\
40 & $0.94 \pm 0.056(31)$ \\
60 & $0.88 \pm 0.052(36)$ \\
80 & $0.70 \pm 0.036(49)$ \\
\hline
\end{tabular}

${ }^{a}$ Cells were pre-incubated with 2,2'DHC for $1 \mathrm{~h}$ then incubated with 1-chloro-2,4-dinitrobenzene at $10^{\circ} \mathrm{C}$ for $45 \mathrm{~min}$ for dinitrophenylS-glutathione (DNP-SG) loading. The DNP-SG-loaded cells were washed with and then incubated in HBSS for 60 min. DNP-SG exported to the extracellular HBSS was determined by HPLC-UV analysis. Values are the means \pm SD of at least three independent experiments.

treatment with $80 \mu \mathrm{M}$ chlorambucil, a $30 \%$ increase in toxicity was achieved by the sensitiser. Statistical differences were observed at concentrations of 20,40 and $80 \mu \mathrm{M}$ in the case of both drugs. The $\mathrm{IC}_{50}$ values for chlorambucil and melphalan are 132.9 and $111.1 \mu \mathrm{M}$ respectively; these values decreased to 76.4 and $52.5 \mu \mathrm{M}$ respectively when the cells were pretreated with 2,2'DHC. However, as shown in Fig. 3, the doseresponse curve of the cells to actinomycin D was not affected by their pre-treatment with 2,2 'DHC. These results suggest that 2,2'DHC sensitises human colon cancer cells to chlorambucil and melphalan, which are substrates of GSH-related detoxification mechanisms, but not to actinomycin $\mathrm{D}$, which has not been previously shown to be detoxified by this system.

Inhibition of cancer cell glutathione S-transferases by 2,2'-dihydroxychalcone. To study the mechanisms of chemosensitisation as described above, the effects of 2,2'DHC on the drug detoxification enzyme GST were assessed. Table I shows the dose-dependent inhibition, by 2,2'DHC with an $\mathrm{IC}_{50}$ value of $28.9 \mu \mathrm{M}$, of the GSH transferase extracted from the human colon cancer cells. Inhibition of the activity of this drug detoxification enzyme by $2,2^{\prime} \mathrm{DHC}$ may contribute to its sensitisation of the cells.

Inhibition of GS-X pump activity in human colon cancer cells by 2,2'-dihydroxychalcone. The export of GSH conjugates of anticancer drugs such as melphalan and chlorambucil is a sequentially separated step of the detoxification system. The effects of 2,2'DHC on this export were therefore studied. As shown in Table II, the export of a typical GSH conjugate, DNP-SG, by human cancer cells was dose-dependently affected by 2,2 'DHC. This inhibition by 2,2 'DHC may also contribute to its sensitisation of the cancer cells.

\section{Discussion}

Chalcones are plant-derived polyphenolic substances widely found in human diets and traditional medicines $(28,29)$. They 
are generally considered non-toxic and have been shown to have various biological and pharmacological effects, including anticancer activity (30). In our previous study, chalcones were shown to inhibit GST activity; a structure-activity analysis showed that hydroxylation substitutions at the C-2' and C-2 positions in ring $\mathrm{A}$ and $\mathrm{B}$ of the chalcone molecule, respectively, are required for the inhibition of GST activity $(10,26)$. 2,2'DHC was therefore selected for this study so that its effects on GST activity in human colon cancer cells and its possible sensitisation of cancer cells to anticancer agents could be investigated.

2,2 'DHC was revealed to be a potent inhibitor of GST activity in human colon cancer cells with an $\mathrm{IC}_{50}$ value of $28.9 \mu \mathrm{M}$. This inhibition may be the mechanism for its sensitisation of human colon cancer cells to chlorambucil and melphalan, which are substrates for GSH-related detoxification. Notably, the toxicity of actinomycin D to these cells was not affected by pre-treatment with 2,2'DHC. As actinomycin D has not been shown to be detoxified by GSH conjugation, modulation of the GSH-related detoxification system in cancer cells should not affect its detoxification or cellular toxicity. Chlorambucil, melphalan and actinomycin D exert their cytotoxic effects on cancer cells through different mechanisms; numerous factors, operating from the time of drug administration to the final achievement of drug effects, may account for drug resistance. These include changes in the influx and efflux of drugs across the tumour cell membrane, alterations in drug activation and detoxification, modulations in the target site and the repair of drug-induced damage. Based on our current data, the possibility that other mechanisms play a role in the sensitisation of cancer cells by 2,2 'DHC cannot be excluded yet. However, 2,2'DHC as a modulator of GSHrelated detoxification mechanisms could sensitise cancer cells to only those drugs which are substrates of GSH conjugation. This further confirms the contribution of increased detoxification by GSH-related mechanisms to the drug resistance of these cells. Relatively non-toxic modulators of this system, such as chalcones, are therefore potential sensitisers for cancer cells resistant to these chemotherapeutic agents.

In this study, 2,2'DHC inhibited the transport of GSH conjugates and GST activity in human colon cancer cells. Although the relative contribution of each of these processes to the sensitisation of the cells was not assessed, they could conceivably provide synergistic effects as they are sequentially separated steps in the overall detoxification system. This property of the polyphenol adds to its potential as a sensitiser for cancer chemotherapy. However, further studies are required to ascertain the other biological and pharmacological effects of 2,2'DHC on cancer and non-malignant cells.

\section{Acknowledgements}

This work was supported by research grants from The National Medical Research Council of Singapore (NMRC/0985/2005 and NMRC/1029/2006). The authors thank the support staff at Melbourne University, Australia and Temasek Polytechnic, Singapore for the recruitment of K.G. and Y.C. to the department. We are also grateful to the staff of the Department of Experimental Surgery, Singapore General Hospital, for their technical assistance.

\section{References}

1. Go RS and Adjei AA: Review of the comparative pharmacology and clinical activity of cisplatin and carboplatin. J Clin Oncol 17: 409-422, 1999.

2. Leung TW, Patt YZ, Lau WY, Ho SK, Yu SC, Chan AT, Mok TS, Yeo W, Liew CT, Leung NW, Tang AM and Johnson PJ: Complete pathological remission is possible with systemic combination chemotherapy for inoperable hepatocellular carcinoma. Clin Cancer Res 5: 1676-1681, 1999.

3. Andre T, Quinaux E, Louvet C, Colin P, Gamelin E, Bouche O, Achille E, Piedbois P, Tubiana-Mathieu N, Boutan-Laroze A, Flesch M, Lledo G, Raoul Y, Debrix I, Buyse M and De Gramont A: Phase III study comparing a semimonthly with a monthly regimen of fluorouracil and leucovorin as adjuvant treatment for stage II and III colon cancer patients: final results of GERCOR C96.1. J Clin Oncol 25: 3732-3738, 2007.

4. Perez RP: Cellular and molecular determinants of cisplatin resistance. Eur J Cancer 34: 1535-1542, 1998.

5. Commandeur JN, Stijntjes GJ and Vermeulen NP: Enzymes and transport systems involved in the formation and disposition of glutathione S-conjugates. Role in bioactivation and detoxication mechanisms of xenobiotics. Pharmacol Rev 47: 271-330, 1995.

6. Zhang K, Mack P and Wong KP: Glutathione-related mechanisms in cellular resistance to anticancer drugs. Int J Oncol 12: 871-882, 1998.

7. Dulik DM, Fenselau C and Hilton J: Characterization of melphalan-glutathione adducts whose formation is catalyzed by glutathione transferases. Biochem Pharmacol 35: 3405-3409, 1986.

8. Zhang K and Wong KP: Glutathione conjugation of chlorambucil: measurement and modulation by plant polyphenols. Biochem $\mathrm{J}$ 325: 417-422, 1997

9. Zhang K, Yang EB, Tang WY, Wong KP and Mack P: Inhibition of glutathione reductase by plant polyphenols. Biochem Pharmacol 54: 1047-1053, 1997.

10. Zhang K and Wong KP: Inhibition of the efflux of glutathione S-conjugates by plant polyphenols. Biochem Pharmacol 52: 1631-1638, 1996.

11. Hall AG, Matheson E, Hickson ID, Foster SA and Hogarth L: Purification of an alpha class glutathione S-transferase from melphalan-resistant Chinese hamster ovary cells and demonstration of its ability to catalyze melphalan-glutathione adduct formation. Cancer Res 54: 3369-3372, 1994.

12. Barnouin K, Leier I, Jedlitschky G, Pourtier-Manzanedo A, Konig J, Lehmann WD and Keppler D: Multidrug resistance protein-mediated transport of chlorambucil and melphalan conjugated to glutathione. Br J Cancer 77: 201-209, 1998.

13. Tew KD, Bomber AM and Hoffman SJ: Ethacrynic acid and piriprost as enhancers of cytotoxicity in drug resistant and sensitive cell lines. Cancer Res 48: 3622-3625, 1988.

14. Hansson J, Berhane K, Castro VM, Jungnelius U, Mannervik B and Ringborg U: Sensitization of human melanoma cells to the cytotoxic effect of melphalan by the glutathione transferase inhibitor ethacrynic acid. Cancer Res 51: 94-98, 1991.

15. Caffrey PB, Zhu M, Zhang Y, Chinen N and Frenkel GD: Rapid development of glutathione-S-transferase-dependent drug resistance in vitro and its prevention by ethacrynic acid. Cancer Lett 136: 47-52, 1999.

16. Anderson CP, Tsai J, Chan W, Park CK, Tian L, Lui RM, Forman HJ and Reynolds CP: Buthionine sulphoximine alone and in combination with melphalan (L-PAM) is highly cytotoxic for human neuroblastoma cell lines. Eur J Cancer 33: 2016-2019, 1997.

17. Burton LL, Lazo JS, Parker KL, Burton I and Blumenthal D (eds): Antineoplastic agents. In: Goodman \& Gilman's The Pharmacological Basis of Therapeutics. McGraw Hill, New York, pp1233-1287, 1996.

18. Ferrari S, Mercuri M, Rosito P, Mancini A, Barbieri E, Longhi A, Rimondini S, Cesari M, Ruggieri P, Di Liddo M and Bacci G: Ifosfamide and actinomycin-D, added in the induction phase to vincristine, cyclophosphamide and doxorubicin, improve histologic response and prognosis in patients with non metastatic Ewing's sarcoma of the extremity. J Chemother 10: 484-491, 1998.

19. Galbraith WM and Mellett LB: Tissue disposition of 3H-actinomycin D (NSC-3053) in the rat, monkey, and dog. Cancer Chemother Rep 59: 1601-1609, 1975.

20. Tew KD: Glutathione-associated enzymes in anticancer drug resistance. Cancer Res 54: 4313-4320, 1994. 
21. Salinas AE and Wong MG: Glutathione S-transferases - a review. Curr Med Chem 6: 279-309, 1999.

22. Zhang K, Yang EB, Wong KP and Mack P: GSH, GSH-related enzymes and GS-X pump in relation to sensitivity of human tumor cell lines to chlorambucil and adriamycin. Int J Oncol 14: 861-867, 1999.

23. Zhang K, Yang EB, Zhao YN, Wong KP and Mack P: Glutathione-related factors are not correlated with sensitivity of human tumour cells to actinomycin D. Cancer Lett 149: 213-220, 2000.

24. Zhang K, Chew M, Yang EB, Wong KP and Mack P: Modulation of cisplatin cytotoxicity and cisplatin-induced DNA cross-links in HepG2 cells by regulation of glutathione-related mechanisms. Mol Pharmacol 59: 837-843, 2001.

25. Habig WH, Pabst MJ and Jakoby WB: Glutathione S-transferases. The first enzymatic step in mercapturic acid formation. J Biol Chem 249: 7130-7139, 1974.
26. Zhang K and Das NP: Inhibitory effects of plant polyphenols on rat liver glutathione S-transferases. Biochem Pharmacol 47: 2063-2068, 1994

27. Bradford MM: A rapid and sensitive method for the quantitation of microgram quantities of protein utilizing the principle of protein-dye binding. Anal Biochem 72: 248-254, 1976.

28. Haslam E, Lilley TH, Cai Y, Martin R and Magnolato D: Traditional herbal medicines - the role of polyphenols. Planta Med 55: 1-8, 1989.

29. Pierpoint WS: Phenolics in food and feedstuffs: the pleasures and perils of vegetarianism. In: Annual Proceedings of the Phytochemical Society of Europe. Van Sumere CF and Lea PJ (eds). Clarendon Press, Oxford, pp427-451, 1985.

30. Middleton E Jr, Kandaswami C and Theoharides TC: The effects of plant flavonoids on mammalian cells: implications for inflammation, heart disease, and cancer. Pharmacol Rev 52: 673-751, 2000 . 